\title{
Läti 20. sajandi ajaloo allikad: suulise ajaloo allikate ja arhiividokumentide dialoog
}

\begin{abstract}
Irēna Saleniece
Teesid: Artiklis põhjendatakse vajadust kasutada Läti 20. sajandi ajaloo uurimisel suulise ajaloo allikaid koos teiste allikaliikidega selleks, et avastada seni mahavaikitud fakte ning muuta ettekujutust minevikust täpsemaks ja mitmetahulisemaks. Näitena on artiklis analüüsitud kahe naise - 25. märtsil 1949. aastal küüditatud ema ja tütre - eluolu, nagu see on fikseeritud nende elulugudes ja arhiividokumentides. Arhiividokumentide ja suulise ajaloo intervjuu ühendamise vajadusest lähtudes osales autor allikakogu 1949. gada 25. martā izvesto balsis (25. märtsil 1949. aastal küüditatute hääled) koostamisel. Toetudes allikapublikatsiooni ettevalmistamise kogemustele käsitletakse artiklis arhiividokumentide ja suuliste allikate kompleksse avaldamisega seotud õiguslikke ja eetilisi probleeme ning allikate arheograafia küsimusi.
\end{abstract}

Märksõnad: arhiividokumendid, intervjuud, kompleksne allikapublikatsioon, Läti ajalugu, märtsiküüditamine

\section{Projekti taust}

Läti 20. sajandi ajalugu on sündmusterikas, olulisimad neist on Läti riigi loomine 1918. aastal ja riikliku iseseisvuse taastamine 1991. aastal. Sõltuvalt suhtumisest Läti riikluse ideesse tõlgendavad ja hindavad erinevate historiograafilise koolkondade ja traditsioonide esindajad Läti ajaloo fakte erinevalt. Need tõlgendused on mõnikord lausa vastupidised, näiteks Läti annekteerimine aastal 1940 on nõukogude ajaloolaste silmis ajaloolise õigluse võit, kuid Läti rahvusliku historiograafia esindajad tunnistavad selle okupatsiooniks. Kumb väide on tõele lähemal? Tõenäoliselt see, mis põhineb ajaloo allikatel kui tunnistustel. Kuid kirjalikud allikad, millest peamiselt lähtub Läti 20. sajandi ajaloo rekonstrueerimine, on enamasti ametlikku päritolu, st need esindavad minevikufakte võimu vaatevinklist.

Totalitaarsete režiimide ${ }^{1}$ ametlike dokumentide puhul tuleb arvestada totalitaarse bürokraatliku süsteemi mõju ja ebameeldivate faktide ignoreerimi- 
sega, samuti on võimalikud avalikud võltsingud. Isegi sellistel juhtudel, kus pole põhjust kahelda allikate autentsuses, võib neis sisalduv informatsioon olla vale. Vaatame konkreetset näidet. Aastal 1949 algas peaaegu ühel ajal kogu Läti territooriumil põllumajanduse massiline kollektiviseerimine. Lühikese aja jooksul ühines enamik maaomanikke kollektiivsetesse majanditesse (kolhoosidesse), andes kolhoosidele tasuta maad, loomi, põllumajandusehitisi ja muud omandit. Nõukogude historiograafias ei rõhutata kollektiviseerimise sunniviisilist iseloomu, sest ei ole puudust ametlikest tõenditest selle kohta, et talupojad otsustasid ise kolhoosidesse astuda - sellele viitavad ka nende omakäeliselt kirjutatud avaldused. Avaldusi, mis tõendavad autorite soovi öelda lahti eraomandist ja asutada kollektiivmajand, hoitakse Läti riiklikes maakonnaarhiivides. Siiski tekitab Läti kollektiviseerimise kiire tempo ja samaaegsus kogu territooriumil kahtlusi selle võimaliku pealesurumise suhtes võimu poolt. Ka kaasaegsed tõendavad eranditeta, et inimesi sunniti selles protsessis osalema. Miks nad siis ise kirjutasid avaldusi?

[---] tulid kolhoosid... (kolhooside ajani oli seal põllumajandusühistu, selles ma olin sekretäriks ja siis tuli kolhoos)... meie majas oli kolhoosi kontor. Olin valitud kolhoosi juhatajaks esimest aastat... noh, mis ma poisike võisin sest aru saada... Tugevalt vastu seista ju kah kuidagi... ei võinud. [---] kohe pärast 25. märtsi [1949. aasta küüditamise kuupäev Lätis] ... jah, kohe... teisel või kolmandal päeval... kutsuti koosolek kokku ja [ütleb]: "Kirjutage avaldusi... kolhoosi! [jutustaja muudab intonatsiooni, kõrgendab häält] Kui tahate... kui ei taha, ei pea kirjutama. Aga siis teadke, mis üleeile oli...” Ühtegi sõna ei öelnud talumees [emotsionaalselt rõhutatult] - noor, vana... Kõik rahulikult kirjutasid need avaldused ja panid talle [valla esimehele, kes koosolekut juhtis] lauale: nad on nõus kolhoosi [astuma] (NMA: 694).

Hirm oli põhjus, miks mitu tuhat Läti elanikku "toetas" nõukogude võimu nõudmisi. Nimetatud juhul olid talumehed mõned päevad varem tunnistajaks sellele, kuidas nende ümbrusest järsku ja kohtuotsuseta olid kadunud naabrid - samasugused talumehed. Samasuguse saatuse kartuses olid põllumehed sunnitud kirjutama avaldusi, milles ei kajastu nende tegelik suhtumine kolhoosi. Sellise tegevusega nõustusid nad vastuvaidlemata andma oma raskelt teenitud omandi ühisesse (ja mitte kellegi) kasutusse.

Järelikult selleks, et arusaam 1940.-1980. aastate sündmustest Lätis oleks võimalikult sügavam, täiuslikum ja täpsem, peab ajaloolane pöörduma suulise ajaloo allikate poole. Suulise ajaloo allikad pakuvad head võimalust saada vahetut informatsiooni mineviku tunnistajate käest, kuid peab arvestama sellega, et see informatsioon on paratamatult ajapikku transformeerunud (Thomp- 
son 2000; Grele 1998: 38). Vaatamata teatud raskustele nende allikate loomisel (Saleniece 2002: 72-74), tagavad just tavaliste inimeste tunnistused (loomulikult komplektis traditsiooniliste allikatega) suuresti võimaluse rekonstrueerida kunagiste suhete reaalsust. Kuid ajalooline tegelikkus kajastub suulise ajaloo allikates vastuoluliselt. Usaldusväärse informatsiooni saamiseks peab suulise ajaloo allikabaas olema piisavalt esinduslik; tuleb arvestada nende allikate spetsiifikaga, mis sõltub inimmälu iseärasustest, samuti poliitiliste, ideoloogiliste jt olude mõjust jutustajale. Sellepärast tuleb juba suulise ajaloo allika loomisel kasutada erinevaid võtteid saadava informatsiooni täpsustamiseks (Friedlander 1998: 318). Suulise ajaloo allikate kasutamisel on vaja hoolikalt kontrollida nendes sisalduva informatsiooni usutavust (Grele 1998: 41), kuid sama tuleb öelda ka töö kohta teiste ajalooallikatega. Suulise ajaloo allikad luuakse intervjueerija ja intervjueeritava tihedas koostöös, sellepärast sisaldavad nad mitmekesist ja -tahulist informatsiooni. Uurija peaks neis allikates eristama vähemalt kolme informatsioonitasandit, sh intervjueerija isiku peegeldus, jutustaja isiksuse kehastumine allikas, konkreetsete ajaloofaktide killud, ning järjepidevalt tegelema igaühega neist (Ivanovs 2002: 79-83).

\section{Näiteanalüüs: 1949. aasta märtsiküüditamine}

Käesoleva artikli aluseks oleva uurimuse allikabaasi moodustavad Läti elanike elulood rahvusliku suulise ajaloo projekti kogust (lühend NMA) (Zirnīte 1996) ja Daugavpilsi Ülikooli suulise ajaloo keskuse kogust (lühend DU MV). Suulise ajaloo allikate tsiteerimisel viidatakse kogu lühendile ja intervjuunumbrile kataloogis. Nende allikate loomise eesmärk on olnud säilitada konkreetse inimese elulugu ja omandada seda informatsiooni, mis on esitatud isikliku eluloo raames. Eluloos avaldub inimese minevik tervikliku kujundina, millele annab koherentsuse jutustaja isiksus ja tema väljendatud suhtumine olnusse.

Suulise ajaloo allikate põhjal on võimalik välja selgitada nii minevikutegelikkust kui ka jutustaja praeguseid arusaamu ja hinnanguid üleelatule (mis läbielatust on tema arvates mainimist väärt ja miks; kuidas suhtub ta praegu kunagi läbielatusse jne). Järgneva analüüsi näiteks valisin kahe naise - ema Irina Grigorjeva (DU MV: 73) ja tütre Glikērija Mukāne (Grigorjeva) (DU MV: 72) - elulood. Mõlema eluloo keskne sündmus on 1949. aasta 25. märtsi küüditamine, mille käigus jutustajate pereliikmed 43000 Läti elaniku seas sattusid Siberisse eriasumisele, elades seal aprillist 1949 oktoobrini 1956.

Intervjuud ja Läti Riigiarhiivi materjalid (LVA, fond 1894, nimistu 1 (Daugavpilsi maakond), säilik 7639) lubavad rekonstrueerida Grigorjevite pere ela- 
mistingimusi. See oli vanausuliste pere, kus kasvas seitse last - kolm venda ja neli õde. 1939. aasta põllumajandusloenduse andmetel kuulus perele enne Teist maailmasõda 28 ha maad, 4 hobust, 8 lehma, 15 lammast, 5 siga, samuti hooned ja põllumajandusinventar. 1940. aasta ja sõda tõi muutusi Grigorjevite ellu. Pojad mobiliseeriti Saksa sõjaväkke, üks neist hukkus sõjatandril, teine - Jevtihi - sattus Nõukogude sõjavangi. Pärast tagasipöördumist ta abiellus ja jäi koos naise Irinaga elama vanemate juurde. Aastal 1948 sündis noorpaaril tütar Glikērija. Argielu sündmustega paralleelselt toimusid ühiskonnas sotsiaalpoliitilised muutused, mis puudutasid ka seda perekonda. 25. septembril 1947. aastal kanti talupidamine kulakute kategooriasse vaatamata sellele, et pärast 1944. aasta põllumajandusreformi ei kuulunud perele enam senine maaomand, muu vara hulk vähenes tunduvalt ning alles olid jäänud vaid tööhobune, kaks lehma, pull, vasikas, viis lammast ja kitse, kolm siga, kolm mesilastaru, muruniiduk, viljaniiduk ja hobulooreha. Lisades hiljem, et talupidamises kasutatakse "süstemaatiliselt palgalist tööjõudu", lülitasid kohalikud võimuesindajad perekonna küüditatavate nimekirja just kulakutena. Tõsi, märgitud oli ka see, et kaks poega olid sõja ajal teeninud Saksa sõjaväes. 27. veebruaril 1949. aastal kinnitas Läti NSV riikliku julgeoleku minister Alfons Noviks otsuse Grigorjevite perekonna küüditamise kohta. Nii sattusid Grigorjevid nende tuhandete perekondade hulka, keda oli kavas ööpäeva jooksul mistahes ettevalmistuseta kodunt välja tõsta ja küüditada. Kui me vaataksime asjadele võimuesindajate positsioonilt, näeks kõik välja võrdlemisi ratsionaalne: selleks, et tagada kolhooside asutamine Lätis, oli loogiline isoleerida (küüditamise teel) need, kes kindlasti tegutseksid selle vastu, keeldudes andmast oma vara ühiskasutusse. Projektil oli lisaväärtusi veelgi: küüditamata, kuid ärahirmutatud kohalike elanike edaspidine vastuvaidlematu kuulekus võimu nõuetele, küüditatute majanduslikult kasulik rakendamine Siberi uudismaade harimisel jne.

Kuid suulise ajaloo allikad pakuvad meile võimaluse vaadata minevikku teisest vaatevinklist - tavainimese positsioonilt, kes vastu tahtmist on kistud ajaloosündmustesse. Ja sellel positsioonil me saame aru, et inimestel ei olnud võimalik ratsionaalselt mõelda kujunenud olukordade üle, sest nende saatuste üle otsustati nende osaluseta, nad olid sunnitud orienteeruma toimuvas pelgalt kuulujuttude abil. Operatsiooni Priboi (Murdlaine) suurele salastatusele vaatamata jõudsid fragmentaarsed, ebaselged ja sünged uudised siiski kohalike inimeste kõrvu ja külvasid kõikehõlmavat hirmu:

[---] eelaimdus oli, sest kogu aeg, ütleme nii: seda juba teati, tunti, et tuleb see kü̈̈ditamine. Nii kui mainis kü̈̈ditamist, nii kohe sees kõik väriseb (NMV: 1572). 
Hirm sundis inimesi otsima väljapääsu: peitma end metsas, andma pistist kohalikele võimuesindajatele või muul moel püüdma vältida ebaselget, kuid hirmsat saatust. Miks inimesed kartsid? Esiteks sundis informatsioonipuudus kujutama ette surmaohtu, sest tundmatu on hirmutanud inimesi alates sellest ajast, mil ta hakkas end inimesena tajuma. Teiseks olid Läti elanikud juba enne seda kogenud massiterrorit ning isegi need, keda see otseselt ei puudutanud, olid hästi informeeritud nii 1941. aasta küüditatute traagilisest saatusest kui ka holokaustist ja teistest massiterrori aktidest. Sellepärast oli 1949. aasta kevadel Lätimaa tardunud hirmust, mis saavutas kulminatsiooni 25. märtsil (Saleniece 2005). Nii jutustavad kaasaegsed:²

[---] algas see kü̈̈ditamine [---] nagu täna mäletan: seisime verandal ja vaatasime aknast välja, kuidas autod mööda sõidavad. Selline varajane hommik oli ja udu selline, aga lund juba ei olnud pea-aegu üldse, rohkem pori, aga nii sõitsid meist mööda. Mõtlesime, kohe pööravad sisse, aga sõitsid mööda (DU MV: 150).

Ka Grigorjevite pere elas selles kasvava ohu õhkkonnas, kuid erinevalt teistest ei püüdnud nad vältida ohtu, sest nende olukord oli eriline - peres kasvas kümnekuune Glikērija:

Люди знали про эти вывозы. В Варкаве, в волости, работала моего мужа племянница, она все знала... каждый день нам передавали вести нам такие. Вот Анна - они там все каждое утро уходили, а мы куда уйдем - у нас ребенок малый....

[Inimesed teadsid nendest väljaviimistest. Vārkavas, vallas, töötas minu mehe õetütar, tema teadis kõike... iga päev saime selliseid teateid. Näiteks Anna - igal hommikul läksid nad kõik ära, aga kuhu meil minna meil väike laps] (DU MV: 73).

Sellepärast nad ainult ootasid sel 25. märtsi hommikul, kui kohale jooksis naaber teatega, et võimuesindajad on tulnud juba teiste naabrite juurde ja kohe-kohe jõuavad ka Grigorjevite juurde. Minia palus sõnumitoojal üksnes võtta ikoon ja viia see majast välja, tõenäoliselt kartes, et maja pannakse põlema ja pühadus hävib. Kui pereliikmed on ohus, jäägu vähemalt Jumala pilt puutumatuna:

Пришел сосед Ваня и сказал: “Сейчас за вами придут... Алейникова забирают, сейчас за вами придут.” А я говорю: “Ванюшка, снеси икону, которая в том конце стоит.” Он забрал эту икону, понес, а они уже на улице окружают. “А ты куда? [на него], а ну, вернись, туда же будем.” Он положил [икону], и когда нас увезли, тогда снес икону. 
[Tuli naabri Vanja ja ütles: "Nüüd tullakse teile järele... Aleinikov võetakse kinni, kohe tullakse teile järele." Aga mina ütlen: "Vanjake, vii ära ikoon, mis seal seisab.” Ta võttis selle ikooni, hakkas minema, aga nemad juba teda tänaval piiravad. "Aga kuhu sina? [mehele] Tule siia, lähme sinna tagasi." Ta pani [ikooni] tagasi ja kui meid ära viidi, siis viis ikooni ära] (DU MV: 73).

Intervjueeritav jutustas suhteliselt napisõnaliselt kinnipidamise ja küüditamise protseduurist. Arhiividokumentide põhjal järeldades on ta mõningad asjaolud segamini ajanud. Näiteks mäletas ta ämma sõnu, mida too olevat öelnud kinnipidamise hetkel, kuid dokumendid näitavad, et ämm viibis sel ajal tütre ja väimehe peres naabervallas ning teda isegi ei küüditatud.

С автоматами пришли... Раньше пришел один, спросил: "У вас дом большой, окна большие, вам надо поставить семь солдат.” Свекор был на мельнице, а свекрова говорит: "Ну что ж, если надо, так ставьте.” А когда забирать, он самый первый зашел с автоматом и второй $c$ автоматом.

[Automaatidega tuldi... Varem üks tuli, küsis: "Teil on suur maja, aknad on suured, teie juurde paigutame seitse sõdurit.” Äi oli veskil, aga ämm ütleb: "Mis seal ikka, kui vaja, siis paigutage." Aga kui hakati ära viima, siis sisenes seesama kõige esimesena automaadiga ja teine tuli automaadiga] (DU MV: 73).

Uurijana kahtlen, kas julgeolekutöötajad ja kohalikud aktivistid, kes selle operatsiooni ellu viisid, plaanisid tõepoolest tulla nii suures koosseisus, et mõnda perekonda kinni pidada. Kuid see liialdus näitab kaudselt seda, millises ärevuses ja kui hirmunud oli jutustaja sel hetkel. Edasi järgnevad eluloos mälestused teest Siberisse ja sealsest elust. Kõige dramaatilisem ja südantlõhestavam episood küüditamise ajast tuli välja ema jutust. Seda me saame teada tütrelt:

... neljakümne üheksandal aastal, kahekümne viiendal märtsil, meie perekonda - isa, ema, tädi - isa õde, mind (ma olin 10-kuune) kü̈̈ditati Siberisse [hääl katkeb, hakkab nutma, edaspidi püüab pisaraid hoida]. Mina loomulikult midagi ei mäleta. Mis ma ema jutust saan nüüd öelda. Kahekümne viiendal märtsil, veel ei olnud kuus, tulid vankriga kolm inimest automaatidega, emal ja isal kästi asjad poole tunni jooksul kokku koguda... ema nõudis, et tal lubataks lehma lüpsta, et võtta piima lapsele. Ta läks aita, ja käed ei kuulanud ... kuidagi lüpsis ... ja enne teeleminekut ta veel toitis mind rinnaga... ja siis kogus kokku kõige vajalikumad 
asjad, kõik istusid vankrisse, ja neid viidi Vārkava jaotuspunkti. Seal koguti kokku, seal juba ootasid veoautod ... siis veeti veoautodega Nīcgale jaama. Kõik olid hirmunud. Ema ütleb isale: “Äkki jätame lapse naabritele? Sest ei ole teada, kuhu meid viiakse. Äkki lastakse kõiki maha..." Isa ütleb: “Умирать, так всем разом умирать..." Kuid siiski ta otsustas Vārkavas, sealsamas meiereis, seal selline tuttav inimene, Vaǵelis, töötas, ja ta andis mind sellele Vaǵelisele, [---] siis mind toimetati isa õe juurde, aga neid viidi Nīcgalesse [ohkab, lõpetab nutmise]. Vanaema tuli nädala pärast ja siis võttis enda juurde, ja nii ta mind kasvatas kahe aasta vanuseni ... viiekümnekuuenda aasta augustikuuni (DU MV: 72).

Jutustus on väga sujuv ning tekib mulje, et seda on räägitud juba mitmeid kordi. Minu meelest on tegemist looga, mis ühendab selles perekonnas neljaviit põlve: Glikērijat, tema ema, lahkunud vanaema (jutustaja ise mõistab selgelt, et juhtunu sai temale teatavaks vaid sellepärast, et seda jutustasid vanemad pereliikmed: "vanaema rääkis, ema rääkis", "Mina loomulikult midagi ei mäleta. Mis ma ema jutust saan nüüd öelda") ja Glikērija laste põlvkonda, võimalik, et ka viiendat põlvkonda - lapselapsi. See lugu on sügavalt sümboolne - see jutustab perekonna jõust ning võimest ellu jääda ja säilitada ühtsust ka rasketes oludes. Pereliikmed, eriti ema, olid vähemalt kahel korral mõeldamatult raske valiku ees. Esimest korda, küüditamise hetkel, tuli valida, kas säilitada perekonna ühtsus, riskides kõigil koos hukka saada, või lahkuda tütrest lootuses tagada talle elu. Kui Siberis selgus, et surmaohtu enam pole, pidi ta teist korda otsustama: kas elada väikelapsest lahus või mitte, vähendades sellega aga tütre tulevikuväljavaateid (Lätti vanaema juurde jäädes säilitanuks Glikērija tavalise staatuse eriliste piiranguteta, kuid Siberisse tulles omandanuks kolmeaastane tüdruk automaatselt eriasumisele saadetu staatuse). Näeme, et üldinimlike väärtuste ja võimu nõudmiste järgimist ei olnud võimalik ühendada. Millised valikud ka polnud, nende tagajärjed olid kindlasti valusad. Irīna tegi oma valikuid, kuid kas see möödus jälgi jätmata?

Ema ja tütre lugusid kuulates on selge, et raskeid üleelamisi põhjustavad mitte mälestused möödunust, vaid rida asjaolusid üleelatuga seoses, mis tegid hirmu ja valu väljakannatamatuks nii sellal kui ka praegu. Mis need asjaolud on?

(1) Sündmuste põhjused ei olnud ega ole selged:

За одни сутки всех забрали. Кого поймают, того забирают... У них такой был приказ - чтобы за одни сутки забрать... Виноват, не виноват - чтобы забрать... 
[Ööpäevaga võeti kõik kinni. Keda kinni püütakse, see ära viiakse... Neil oli selline käsk - ühe ööpäevaga kõik kinni võtta... Süüdi, süütu et aga kinni võtta...] (DU MV: 73).

(2) Kinnipidamise hetkel ja teel Siberisse piinas inimesi teadmatus tuleviku suhtes:

Ой, вы знаете, страшно было [плачет]. Две недели везли в телячьих вагонах... А когда приехали на станцию, сказали: “Приготавливайтесь, на следующей станции будете вылезать.” Мы в слезы, в гвалт - весь этот вот наш эшелон, не эшелон - вагон. В слезы, что в болото привезут, расстреляют нас. [---] Глядим - свет: огонек, еще огонек... стал поезд останавливаться. Тогда нам сказали, каким вагонам вылезать, а остальных повезли дальше. И в клуб нас поместили, сказали: “Ожидайте, когда за вами приедут на конях, быках, и на тракторах за вами приедут.” Один старичок умер, девочка с нами рядом была умерла (два года было). Несправедливо было...

[Oi, teate, hirmus oli [nutab]. Kaks nädalat veeti loomavagunites... Aga kui jõudsime jaama, öeldi: "Pange end valmis, järgmises jaamas ronite maha." Meie kõik pisarates, kisendame - kogu meie ešelon, mitte ešelon - vagun. Pisarates, et viiakse meid sohu, lastakse meid maha. [---] Vaatame - valgus: tuluke, veel üks tuluke... rong hakkas peatuma. Siis öeldi meile, millistest vagunitest peavad välja tulema, aga ülejäänuid veeti edasi. Ja paigutati meid klubisse, öeldi: "Oodake, kuni teile järele tullakse, hobuste, härgadega, traktoritega tullakse järele.” Üks vanamees suri, meie kõrval oli tüdruk - suri (kaheaastane oli). Ebaõiglane oli...] (DU MV: 73).

(3) Ebaõiglus:

- [---] в Сибирь отправили...

- Расскажите, как это получилось? Почему это так?

- И чтобы нас забирала наша волость... A нас забирала другая волость [с обидой, начинает плакать] - Варкавская волость забирала, а мы были Даугавпилсской волости... [---] Враги были... И потом соседи, свои, русские [выдали] ...

- $А$ чем вы провинились?

- 27 гектар у нас было земли...

[[---] Siberisse saadeti...

Rääkige, kuidas see juhtus? Miks nii? 
Ja oleks, et oma vald oleks kinni võtnud... Meid võttis kinni teine vald [hakkab haavunult nutma] - Vārkava vald võttis kinni, aga meie olime ju Daugavpilsi vallast... [---] Vaenlased olime... Pealegi - naabrid, omad, venelased [andsid välja]...

Milles teid süüdistati?

27 hektarit maad oli meil...] (DU MV: 73).

Selles katkendis on nimetatud nelja asjaolu, mis jutustaja meelest viitavad suurele ebaõiglusele tema perekonna küüditamisega seoses. Talu asus Daugavpilsi maakonnas Kalupe vallas (jutustaja mainib Daugavpilsi valda, ent see ei ole õige - sellist valda ei olnud), kuid küüditamise korraldajad tulid naabruses olevast Vārkava vallast. Vana naine näeb selles asjaolus mitte ainult formaalset rikkumist, vaid võõraste sekkumist korrastatud ellu ja normaalse korra hävitamist. On selge, et midagi ei muutuks, kui küüditamise hommikul oleksid Grigorjevi tallu tulnud aktivistid oma vallast, kuid jutustaja meelest on see väga oluline - tuleb võõras ja otsustab. Kõige raskem - see, mis endiselt paneb südame valutama - on ebaõiglane süüdistus, perekonda aastakümneid saatnud tähistus "rahvavaenlased" (враги были...). Ametlikes küüditamisdokumentides figureerisid nad kulakutena. Arvatavasti pidid nad nõukogude ajal sageli kuulma seda nii argielus kui ka ajakirjanduses neile kohaldatud, kuid neile endile vastuvõetamatut määratlust "rahvavaenlased". Perekonnas käibib versioon, et nende küüditamise üks põhjusi oli naabrite pealekaebamine. Naabrid olid venelased, samuti nagu Grigorjevid, ja seda suhteliselt lätlaslikus ümbruses. Pealekaebamine tegi omadest reeturid - seega veel üks pettumine ja kõrvalekalle normaalseks peetavast. Lõpuks oli Läti Vabariigis sündinud ja kasvanud naisel maaomand - jõukuse ja ümbritsevate inimeste austuse allikas. Uutes tingimustes ilmnes, et see varandus võib saada omaniku õnnetuste põhjuseks: ajavahemikus 1944-1949 pidi ta alguses leppima maa äravõtmisega ning seejärel kunagise jõukuse tõttu kannatama veelgi. Seega jäi kogu olukord jutustajale arusaamatuks ja vastuvõetamatuks. Tema maailm hävitati ühe silmapilguga - eitati tavapäraseid norme ja väärtusi, ohustati perekonda ja isegi elu. Selle pani toime võim - jõud, mis oleks pidanud hoolt kandma tema turvalisuse eest ja hoidma korda. Nendesse suhtuti nagu kurjategijatesse, kuid mille pärast?

Küüditatutel ei olnud muud kaitset, kui vaid Jumal. Ka Lätti jäänud pöördusid oma nõutuses ja ahistuses Jumala poole, sest polnud kedagi teist, kellele apelleerida:

Oudselt raskelt läks see rong [Eglaine jaamast]. Meie jooksime ette ja pistsime pühitsetud leiba rööpa alla, nagu ema meil käskis. [---] Meil oli 
oudne hirm. Minul üksteist aastat, vennal - seitse. Ja nü̈̈d me heitsime risti igale vagunile. Noh, jõudsime, ei jõudnud, kuid risti heitsime. Siis ma kuulsin: [---] mõnes vagunis lauldi, mõnes mängiti. Ühes vagunis mängiti kitarri. Nii läksid need lätlased (DU MV: 24).

Minevikuhirm jäi inimestesse ja püsib ka tänapäeval (Saleniece 2005). Väga sümboolselt kõlab vana naise jutus, kes meenutab end kunagise tüdrukuna. Ta ise ei mäleta, ei saagi mäletada neid dramaatilisi sündmusi, sest ta oli siis päris väike. Kuid ka tema oli sellal kistud hirmukeerisesse. Praegu arvab ta, et tema enda keha meenutab talle kunagist õudust. Praegust füüsilist valu seostab ta otseselt hirmuga, mille ta sai koos emapiimaga:

Ja sellest hirmust, kui ema [25. märtsi hommikul] toitis mind rinnaga (ma olin juba selline tugev, seisin jalul ja käisin juba käe juures, kui mind veeti), siis jäin jalgadeta, ei saanud käiagi ... nii vanaema räägib, ema räägib. [---] Vist sellest hirmust. [---] Siiski raviti terveks, kuigi see minule ... hiljem, vanemas eas, vist tegi komplikatsioone, ja jalad mul ka praegu valutavad... (DU MV: 72).

Kunagi läbielatud, kuid unustamatul hirmul on kalduvus omandada uusi jooni ja kummitada inimest kogu aja:

- [неразборчиво - из-за надрывного плача] Я говорю: “Доченька, Кира, ты, может, обижаешься на меня, что я тебя оставила? А если бы тебе так пришлося, Свету [внучку рассказчицы, дочь когда-то оставленной на год в Латвии дочери] ты оставила бы или не оставила?” Она [Гликерия, дочь рассказчицы] замолчала, ничего не сказала.

- Вы же не знали, что с вами будет...

[[arusaamatult - katkendliku nutu pärast] Mina ütlen: "Tütreke, Kiira, võib-olla sa solvud minu peale, et ma sind jätsin? Aga kui sinuga nii juhtuks, kas sa Sveta (kunagi aastaks Lätti maha jäetud tütre tütar) jätaksid või ei jätaks [lapse maha]?"Ta [Glikērija,jutustaja tütar] vaikis, ei öelnud midagi.

Te ju ei teadnud, mis teist saab...] (DU MV: 73).

Nagu näeme, ei lõpe ema kannatused perekonna taasühinemisega või perekonna naasmisega koju. Pool sajandit elab ta hirmus, et tütar ei andesta "reetmist" - seda, et 25. märtsil 1949. aastal kiskus ema ta endast lahti. Elu lõpus, mil inimesed veedavad aega peamiselt puhates ja mõtiskledes, näib südamepiin suurenevat. Kodune õhkkond viitab suurele armastusele ja hoolitsusele, millega siin temasse suhtutakse. Vaevalt heidaks tütar talle midagi ette. Kuid intervjuu käigus vana naine justkui õigustab end korduvalt, mõnikord jutus- 
tuse teemaga mitteseotult : ei olnud teada, kas neid viiakse elama või surema; ešelonis poleks olnud võimalik imikut korralikult toita ja hooldada; väikesed lapsed surid teel jne. Tõenäoliselt hajus ajapikku alguses nii tugev hirm surma ees, millest ema tütart päästa püüdis. Surmaoht ei realiseerunud: see, mis 1949. aasta märtsis tundus täiesti võimalik, oli vaid kujutelm. Seevastu "reetmine" tütre suhtes toimus - ema andis ta võõra inimese kätte. Praegu tollast kogemust distantsilt vaadates hindab ta oma tegevust hoopis teisiti ja süüdistab ennast valesti tehtud valikute pärast. Seega ei ole omal ajal läbielatu ainult minevikufakt, see on ka olevikureaalsus. Seda tõdemust peab suulise ajaloo uurimisel ka arvestama.

Irina Grigorjeva ja Glikērija Mukāne elulood on lindistatud 2003. aasta suvel Daugavpilsi Ülikooli ajaloolaste ekspeditsiooni käigus Daugavpilsi maakonna Vabole vallas. Nad jätsid väga tugeva mulje nii intervjueerijale kui ka teistele, kes hiljem kuulasid nende lugude lindistusi. Keegi ei saanud jääda ükskõikseks, kui kuulasid jutustust noorest emast, kes 25. märtsil 1949, kartes küüditatud perekonda ees ootavat tundmatust, otsustas jätta kodumaale 10-kuuse tütre. Meie, kes oleme sündinud aastail 1960.-1980, tunneme järsku seda valu ja ahastust, mida pidi läbi elama meiega samas piirkonnas elanud naine enam kui 50 aastat tagasi. Meid isiklikult mittepuudutanud ja seni vaid teoreetiliselt teadaolev küüditamise sündmus liigutas sügavalt, ühendades meid sellega elusa ja valuliku närviga. Sellepärast kõnetasid Daugavpilsi Ülikooli suulise ajaloo keskuse liikmed järgnevatel ekspeditsioonidel juba erilise tähelepanu ja huviga neid, kes olid ise küüditatud või olid tunnistajateks sellele, kuidas toimus 25. märtsi 1949. aasta küüditamine. Ekspeditsioonides osalejatel ei olnud eesmärki intervjueerida just nimelt küüditatuid. Kõigil intervjueeritavatel paluti jutustada oma elust ja ainult inimesest endast sõltus, millest ta rääkis. Mälestused sündisid spontaanselt, jutustaja ise määras loo sisu, rõhuasetused ja väljaöeldud hinnangud. Kunagised küüditatud vormisid oma eluloo ühe keskse sündmuse - küüditamise - ümber.

Küüditatute elulood loovad teatud kontrasti historiograafiale, sest ajaloolaste analüüs tugineb peamiselt allikatele, mille on loonud võimuesindajad küüditamiste ideoloogid, korraldajad ja elluviijad. See lubab dešifreerida väikseimaidki võimu seisukoha nüansse, kuid võimu mõju objekti - küüditatute olukorda näitab kaudselt, ametlikust võimupositsioonist. Nii tekib kasvupinnas stereotüüpseks ettekujutuseks küüditatutest kui olude ohvritest ja kannatajatest, kelle tegevuse määras läbinisti võim. Massiteadvuses sobib selline iseloomustus hästi suhteliselt primitiivse ajalookontseptsiooni loomiseks, kus inimeste elu minevikus on värvitud vaid kahte värvi - musta ja valgega, kus puudub ruum inimese vabaks väljenduseks, s.o inimese enda valiku tulemusel sooritatud tegevusele. Ei saa siiski eitada elu kirevust, samuti ei saa taan- 
dada inimese elu ühe rolli täitmisele. Isegi vabaduse täieliku puudumise korral jääb valik: leppida vabaduse puudumisega või võidelda sellega vähemalt sisemiselt, suhtumise tasemel.

Näiliselt lootusetus olukorras, kus mitmenädalase sõidu järel tundmatusse sattusid nad Siberisse ja olid sunnitud andma allkirja, et jäävad sinna "igaveseks, õiguseta eelmistesse elupaikadesse tagasi pöörduda", toibusid inimesed imekiirelt ja hakkasid tegutsema. Suulise ajaloo allikatest on teada, et küüditatud korrastasid olmelisi asju: ehitasid või ostsid maju elamiseks, soetasid lehmi ja sigu, et oleks toitu, lõid kontakte kohalike elanikega, hoidsid ühendust kodumaale jäänutega. "Natsionalistidest" pereisad olid mõistetud süüdi ja küüditatud juba varem; juba lähenes nende karistustähtaja lõpp, kuid 1949. aasta märtsis kisti kodunt teised pereliikmed. Mõneks ajaks katkes habras side, mida küüditatud suutsid siiski taastada, saavutades perekondade taasühinemise kui mitte kodumaal, siis vähemalt Siberis. Ametlikes küüditamisplaanides polnud perekondade ühinemise mehhanism sätestatud ja ka vahendeid selleks polnud eraldatud. Sellepärast tegid pereliikmed vaatamata totaalsetele piirangutele ja vabaduse puudumisele kõik täiesti ise ja saavutasid soovitu. Ühtlasi kirjutasid nad avaldusi ja kaebusi võimuesindajatele ja institutsioonidele. Vastused olid peamiselt eitavad, kuid see ei andnud põhjust lüüa kõigele käega ja leppida, ei takistanud ikka ja jälle võtmast sulge, et kirjutada avaldusi, otsimaks vabanemisvõimalusi.

Selline oli jäämäe nähtav osa - küüditatute enda ja oma pere säilitamisele suunatud tegevused, millest me saame teada nii arhiividokumentide kui ka suulise ajaloo allikate kaudu. Siseelu, enesetunne ja vaimne vastupanu arhiividokumentides üldiselt ei kajastu. Seevastu suulise ajaloo allikad annavad võrdlemisi palju teavet sellest, kuidas küüditatud (loomulikult mitte avalikult) vastandasid oma suhtumist ja arusaamu asjade olemusest ametlikele seisukohtadele. Otseste ja kaudsete tunnistuste diapasoon on lai - spontaansest väljendist “Когда Сталин сдох...” [Siis, kui Stalin kärvas...] mälestusteni enam või vähem edukatest katsetest "tõmmata alt" kohaliku võimu esindajaid, lõpetades põlgliku suhtumisega riikliku autasu suhtes. Aastal 2004 suulise ajaloo ekspeditsiooni ajal Saliena vallas demonstreeris Ritvalds Redzobs medalit Uudismaade Ülesharimise Eest (За освоение целинных земель) ja tunnistust, millega teda autasustati aastal 1957, mil ta oli eriasumisel - küüditatu. On üllatav, et küüditatud, kellelt olid võetud kõik vabadused ja peaaegu kõik õigused, tunnistati ühtlasi riiklike autasude vääriliseks. Austasustatu ise ja tema naine mäletasid seda fakti küll vähimagi austuseta, pigem utilitaarselt, mainides, et medal osutus hiljem soodustavaks asjaoluks pere eriasumiselt vabastamisel (DU MV: 195; 401). 


\section{Allikapublikatsioon: dialoogivõimalused küüditamise uurimisel}

Hoolimata sellest, kui rikkalikku informatsiooni suulise ajaloo allikad ka annavad, ei saa nüüdisaja ajaloolane piirduda vaid ühte liiki allikate kasutamisega. Et seletada inimese tegevust minevikus, on tarvis laia ja mitmekesist allikabaasi, sest ainult paljude erinevate allikate võrdlus võimaldab avada inimese eksistentsi eri tahkusid ning mõista ajalooprotsessi keerukust ja iga sündmuse kordumatust. Esiteks saame 1949. aasta 25. märtsi küüditamise uurimisel kasutada arhiividokumente. Täiesti salajase operatsiooni Priboi ettevalmistamise käigus alustati andmete kogumist iga küüditamisele mõistetud ja hiljem küüditatud pere kohta. See jätkus ka teel Siberisse, eriasumise kohas ja rehabilitatsiooni käigus 1980. aastail. Tulemusena tekkis muljetavaldav dokumentide kogum - 13358 küüditatud pere toimikut, mida säilitatakse Läti Riigiarhiivi fondis nr 1894. Kuid see hiiglaslik kogum ja selles oleva informatsiooni maht pole piisav isegi uuritava sündmuse täisväärtuslikuks rekonstrueerimiseks, rääkimata sügavamast mõistmisest. Arhiividokumendid avavad meile minevikku võimupositsioonidest lähtuvalt ja ignoreerivad peaaegu täielikult sündmustesse kaasatud inimeste individuaalset kogemust. Ainult inimesed ise teavad, mida nad tundsid ja millest mõtlesid kinnipidamise, küüditamise ja võõrsil elamise ajal. Ainult nemad mäletavad, kuidas õppisid orienteeruma võõras Siberi looduses ja võõraste inimeste seas, kuidas suutsid kohaneda uute tingimustega - eluga eriasumisel ja tööga kolhoosis. Vajadus arhiividokumentide ja suulise ajaloo allikate ühendamise järele on ilmne.

Koostöö Läti Riigiarhiivi ja Daugavpilsi Ülikooli suulise ajaloo keskuse vahel algas arhiivi töötajate initsiatiivil. Arhiivist otsiti üles küüditatud Grigorjevite, Redzobside, Kalvānsite ja Skladovite pereliikmete toimikud. Samade inimeste elulood olid Daugavpilsi Ülikooli suulise ajaloo keskuse kogus. Arhiividokumentides ja suulise ajaloo allikates sisalduva informatsiooni võrdlemisel tuvastati, et kaht liiki allikate üheaegne kasutamine teeb sündmuste rekonstruktsiooni palju sügavamaks ja täisverelisemaks, mõnikord annab isegi vastuseid, milleni pole võimalik jõuda ainult ühe allikaliigiga töötamisel. Läti Riigiarhiivi ja Daugavpilsi Ülikooli suulise ajaloo keskuse koostööna avaldati allikapublikatsioon 1949. gada 25. martāizvesto balsis (25. märtsil 1949. aastal küüditatute hääled), milles on ühendatud mõnede Daugavpilsi ja Ilûkste maakonnast küüditatud perede esindajate elulood ja nendest peredest küüditatute toimikud (Saleniece 2008).

Allikapublikatsioonide ettevalmistamisel - dokumentide otsimisel, valimisel, trükivalmiks toimetamisel (vt Pravila 1990) - kipuvad tekkima ootamatud 
pöörded, mõnikord on tarvis teha korrektiive. Arhiividokumentide ja suulise ajaloo allikate koosavaldamisega seondub dokumentide valikust tulenevalt rida iseärasusi. Esiteks tuleb arvestada õigusliku aspektiga. Tegeldes 1949. aasta 25. märtsi küüditamise uurimisega sekkume oma kaasaegsete eraellu. Nii arhiividokumendid kui ka suulise ajaloo allikad sisaldavad informatsiooni, mis on sageli sügavalt isiklik ja mille avaldamine võib puudutada inimeste tundeid. Nendel inimestel on kõik õigused olla kaitstud soovimatu sekkumise eest nende privaatsfääri. Vastavalt Läti Vabariigi Fü̈̈siliste isikute andmekaitseseadusele on tarvis saada isikute luba nendega seotud (näiteks nende arhiivitoimikus oleva) informatsiooni kasutamiseks ja avaldamiseks. Suulise ajaloo allikad, mis tekivad intervjueerija ja intervjueeritava koostöö tulemusel, on seotud ka autoriõiguste küsimusega (Baum 1991: 74; Sommer \& Quinlan 2002: 13-14). Intervjueeritav ja intervjueerija on suulise ajaloo allika kaasautorid, mistõttu nende õigused esitatud informatsioonile peavad olema kaitstud, nagu seda nõuab Läti Vabariigi Autoriõiguste seadus. Küsimus laheneb üldiselt jutustaja ja intervjueerija (kes tavaliselt esindab suulise ajaloo asutust) kokkuleppega, mis sätestab lindistuse säilitamise üksikasjad ja annab õiguse kasutada informatsiooni uurimiseesmärgil (MacKay 2007: 28; Baum 1991: 10). Suulise ajaloo allika talletamisel ja kasutamisel tuleb seaduslikust aspektist arvestada kolme suhteliigiga: suhted intervjueeritava ja intervjueerija vahel, suulise ajaloo allika ja arhiivi vahel ning arhiivi ja allika kasutajate vahel. Nimetatud suhete seaduslikuks järgimiseks on vajalik dokumentaalne vormistatus (MacKay 2007: 33-34). Peamine vastutus lasub arhiivil, kus hallatakse suulise ajaloo allikaid tähtajata valduse tingimustel (Baum 1991: 74). Arhiiv on huvitatud, et dokumente ei kasutataks kuritahtlikult intervjueeritavate, intervjueerijate ega intervjuudes nimetatud inimeste suhtes (näiteks jutustaja räägitud valede, kompromiteerivate, häbistavate andmete või eksitavate iseloomustuste ja hinnangute avaldamisega) (Sommer \& Quinlan 2002: 19). On väga oluline, et inimeste tundeid ei riivataks ja et nende (etnilisi, usundilisi, ealisi, soolisi jms) erinevusi respekteeritaks. See nõuab vastutust nii intervjueerijalt, jutustajalt kui ka suulise ajaloo allika kasutajalt, kes tegeleb nende tekstidega uurimisega või kasutab neid muul eesmärgil. Ametliku loa saamine ei vabasta uurijat suurest moraalsest vastutusest intervjueeritud inimeste ja nende sugulaste ees.

Teise eri liiki allikate koosavaldamise iseärasusena õigussätete arvestamise kõrval tuleb arvesse eetiline aspekt, mis on sama oluline ja komplitseeritud kui seaduslikkus. Kogemus näitab, et suulise ajaloo allikate kaasamine avaldatavate allikate kompleksi sunnib väga tähelepanelikult kaaluma iga dokumentidega kinnitatud fakti või detaili avaldamist. Alati on olemas võimalus, et arhiividokumentide avaldamiseks lubamisel ei ole inimesed olnud täielikult 
informeeritud nende sisust. Võimalik, et dokumentides on mainitud asjaolusid, mida nad ei tahakski laiemale üldsusele teatavaks teha. Sellele viitavad mittevastavused jutustajate poolt esitatud informatsiooni ja arhiividokumentide sisu vahel. Uurija peab hoolikalt kaaluma iga konkreetset juhtumit, et lõplikult otsustada dokumendi kaasamine avaldatavasse kogumikku.

Näiteks eitas üks jutustaja intervjuu käigus oma pereliikmete võimalikku teenistust Saksa sõjaväes Teise maailmasõja ajal, mis võis olla pere küüditamiseks põhjuseks:

Aga näiteks kas keegi oli Kaitseliidus või Saksa armees?

Ei.

Mitte keegi?

Saksa armees ei olnud.

[---] Läti Vabariigi ajal oli ehk aktivist vallas? [---]

Seal ema saab ehk paremini [täpsemini] öelda. [---] Tema teab rohkem (DU MV: 72).

Arhiividokumendid näitavad aga üheselt, et nii jutustaja isa kui ka onu (isa vend) teenisid Saksa sõjaväes ja ka vanaisa oli süüdistatud koostöös natsidega osalemise tõttu sõja ajal Saksamaal mingisugusel põllumeeste kongressil. Näib, et mõlema informatsiooniallika - eluloo ja arhiividokumentide - ühine avaldamine tekitab ebaselgust ja segadust. Vastuolud on sageli siiski loogiliselt seletatavad: jutustaja on sündinud pärast sõda (1948), sellepärast ei saa ta teada sõjaaegseid fakte. Tema perekonna küüditamist ja rahvavaenlase templiga veedetud aastaid teades peab arvestama, et vanemad pereliikmed ei pruukinud laste juuresolekul mainidagi asjaolusid, mis olid nõukogude võimu silmis kompromiteerivad. Ka jutustaja ise mõistab oma puudulikku informeeritust ja suunab intervjueerija oma ema juurde, kes "teab rohkem". Ema eluloos aga mainitakse, et tema mees teenis Saksa vägedes. Seega pole põhjust kahelda vastavate dokumentide avaldamise eetilisuses.

Allikate esitamisel järgiti kõnesolevas kogumikus arhiividokumentide (Pravila 1990: 100-122) ja fonodokumentide (Pravila 1990: 151-153) avaldamise eeskirju. 1949. aasta küüditamise dokumentide kohta kehtib sama, mis on üldisemalt iseloomulik NSV Liidu kohtueelse uurimise, vanglate ja laagrite dokumentatsioonile (Sokolov et alii 2004: 153-210). Nii kulakute kui ka natsionalistide toimikute struktuur on ühesugune - perekonna kui terviku kohta käivad toimikud ${ }^{4}$ ja perekonna täiskasvanute liikmete isiklikud toimikud. ${ }^{5}$ Toimikute struktuur kinnistus sellisena 1980. aastate lõpul, mil eriasumisel olnute isiklikud toimikud, mis olid seni hoiul küüditamise sihtkoha arhiivis (käesoleval juhul Omskis), lisati Läti NSV Siseministeeriumi infokeskuses olevale 
toimikule. Võimalik, et samal ajal rikuti dokumentide toimikutesse lisamise korda. Lehed, mis puudutavad eraldi pereliikmeid, on köidetud kokku nende isikliku toimiku lehtedega kronoloogilises järjekorras.

Küüditatud pere toimikus leidusid järeldusotsus pere küüditamise kohta ja otsuse aluseks olevad dokumendid: ärakiri kulakuperede nimekirjast, kes kuuluvad küüditamisele NSVL "kaugetesse kohtadesse" vastavalt Läti NSV Ministrite Nõukogu otsusele; teatis 1939. aasta põllumajandusloenduse andmete põhjal, mille valmistasid ette Läti NSV Riikliku Julgeolekuministeeriumi töötajad; teatis majapidamise suuruse kohta valla täitevkomitee majapidamisraamatute andmete põhjal; teatis ringkonna sõjakomissariaadist, et keegi pereliikmetest pole teeninud ega teeni Punaarmees, ei ole olnud partisanide rühmas ega autasustatud ordenitega. Niinimetatud natsionalistide perede toimikutes leiduvad ka Riikliku Julgeolekuministeeriumi teatised süüdimõistetud natsionalisti kohta; ärakiri sõjatribunali (või muu kohut mõistnud asutuse) otsusest.

Eriasumisele saadetu isiklikus toimikus pidid vastavalt Isikliku toimiku vormistamise korrale olema järgmised dokumendid: eriasumisesele saatmise põhjendus; küüditatu ankeet koos fotoga; küüditatu allkiri selle kohta, et temale on teatatud NSVL Rahvakomissaride Nõukogu 1945. aasta 8. jaanuari otsus nr 35; küüditatu allkiri selle kohta, et ta on tutvunud NSVL Ülemnõukogu Presiidiumi 1948. aasta 26. novembri ukaasiga; eriasumisele saadetu kontrolli ja igakuise registreerimise lehed; otsused halduskaristuste kohta; teatised agentide ettekannete ja teiste kompromiteerivate materjalidega küüditatu kohta; andmed perekonnaseisu (pereliikmete sünd, surm jms) või elukoha muutuste kohta jms.

\section{Eriliigiliste allikate koosavaldamise probleeme}

Küüditatud perede toimikud kuuluvad NSV Liidu kohtueelse uurimise, vanglate ja laagrite dokumentide hulka ning nende kajastamiseks tuleb kasutada vastavat arheograafilist tehnikat. Peab järgima ka mõningaid avaldatavate dokumentide iseärasusi, mis määravad arheograafilise töötluse spetsiifika.

Esiteks on toimikute maht erinev - 244 lehest Grigorjevite pere toimikus veidi üle 100 leheni Skladovi pere toimikus. Esimese perekonna liikmed olid kirjavahetuses ametlike instantsidega. Sellisel juhul hoiti toimikus nii palve esitaja avaldused ja ametlike asutuste kirjavahetus (taotlused, teatised, saatedokumendid jm) kui ka ametlik vastus - tavaliselt negatiivne, millest palujale anti teada suuliselt; vastuse kättesaamise kohta nõuti ka allkirja, kuid dokumenti ennast hoiti toimikus. 
Teiseks on arhiividokumentides sageli eesnimed, perekonnanimed, kohanimed jt kirja pandud vigaselt. Osaliselt on see seletatav asjaoluga, et dokumente kirjutati vene keeles ja kirjutajail olid lätikeelsete nimede ja nimetustega raskusi. Näiteks Redzobide pere toimikus on kirjutatud Mirdza asemel Мирза, Ritvaldsi asemel Ритвольд jne. Kuid vead ei puudu ka vene nimede ja perekonnanimede kirjutamisel. Näiteks Jevtihi (Евтихий) esineb ka kujul Jefim (Ефим), Glikērija (Гликерия) kujul Angelina (Ангелина). See viitab minu meelest sellele, et vaatamata inimese totaalsele jälgimisele ja kõikehõlmavale reglementeerimisele, mis lõi illusiooni, et igaühele on pööratud suurt tähelepanu ja igaüht jälgitakse nagu mikroskoobi all, valitses NSV Liidu repressiivaparaadi tegevuses üllatav hoolimatus konkreetse inimese suhtes - mis vahet, mis on tema õige nimi. Silmatorkav on ka võimuesindajate soovimatus süveneda konkreetsetesse olukordadesse ja lahendada tekkinud sisulisi probleeme, kui välised näitajad vastasid nõudmistele. Näiteks Grigorjevite pere toimikus on dokument nimega Teatis (Справка), mille järgi küüditatavate nimekirja kantud Angelina (tegelikkuses Glikērija) ei olnud vagunis, vaid on jäetud Lätti. Tõenäoliselt pani erivolinik lapse puudumist vagunis tähele alles teel olles ja kiirustas sellest teatama. Kuid kõrgemalseisev ametiisik kirjutas dokumenti kättesaamisel sellele pliiatsiga: “Зачем эта справка?” [Milleks see teatis?]. Näib, et küüditavate inimeste arv ešelonis vastas plaanitud kogusele, seepärast polnud tema meelest muretsemiseks põhjust. Kusagil ei nõutud ju aruandeid kvaliteetsete näitajate kohta, samuti ei pidanud õigustama perekondade lahkulöömist.

Kolmandaks peab rõhutama raskusi, mida põhjustab spetsiaalse terminoloogia tõlkimine läti keelde. Näiteks pole lihtne leida ekvivalente sellistele moodustistele nagu оперуполномоченный, ${ }^{6}$ спецпоселение ${ }^{7} \mathrm{jm}$.

Erinevalt arhiividokumentidest, mida Lätis avaldatakse juba ammu ja asjatundlikult, ei ole suulise ajaloo allikaid meil peaaegu kunagi publitseeritud. Mõned erandid (Zirnīte \& Hinkle 2003) ainult kinnitavad seda fakti. Mujal maailmas on suulise ajaloo allikate avaldamise traditsioonid vanad ja stabiilsed. Näiteks töötati USAs juba 20. sajandi keskpaigas välja suulise ajaloo allikate avaldamise nõuded ja võtted, mida spetsialistid pidevalt arutavad ja täiustavad.

Üks olulisimaid suulise ajaloo allikate avaldamise kvaliteedikriteeriume on loo autentsuse maksimaalne säilitamine. Kuid foneetilist transkriptsiooni suulise ajaloo allikate avaldamisel ei kasutata. Siin lähtutakse kompromissist: autentset kõla säilitab audiolindistus, mida peetakse allika primaarseks vormiks (MacKay 2007: 22; Ives 1995: 80). Tegelikkuses on see küsimus üsna komplitseeritud: kui oletame, et primaarseks allikaks peetakse sellist allikat, enne mida pole mitte midagi peale minevikutegelikkuse, on primaarne interv- 
juu, mis lindistatakse infokandjale. Sellisel juhul on lindistus sekundaarne allikas. Kuid intervjuu on ainulaadne ja kordumatu akt, mille järel jääb alles vaid lindistus. Sellepärast tuleb suulise ajaloo primaarseks allikaks pidada lindistust ja sekundaarseks transkriptsiooni (Ives 1995: 74-75). Mõnikord tunnistatakse teravate diskussioonide taustal primaarsete suuliste allikatega võrdväärseks nii lindistus kui ka transkriptsioon (Baum 1991: 39), kuid laiemale uurijate ja huviliste ringile pakutakse kirjakeele normidele vastavat transkriptsiooni (Baum 1991: 29; Sommer \& Quinlan 2002: 76; Ives 1995: 81). Avaldamise korral seda redigeeritakse, mille lubatavuse piiride üle toimuvad tõsised diskussioonid (Baum 1991: 30-40): sõltuvalt uurija teaduslikest huvidest võib olla oluline intervjuu eri aspektide võimalikult täpne säilitamine. Samuti arutatakse, kas on lubatav publikatsioonist mõne intervjuukatke väljajätmine (sisuga mitteseotud katked, näiteks vestlus kohvi joomise ajal; oodatud või ootamatu külaliste saabumisega seotud vahepalad jms), kas on tarvis säilitada kordusi, kas ja kui ulatuslikud kommentaarid on lubatavad jms.

Väljavalitud intervjuude avaldamiseks ettevalmistamisel kohtasime veel mõningaid raskusi. Esiteks tekkisid probleemid intervjuu käigus toimuva kommunikatsiooni mitteverbaalse sisu peegeldamisega, mida jutustaja demonstreerib žestide, miimika, emotsionaalsete väljenditega jne. Spetsialistid arvavad, et on soovitav jutustaja mistahes väljundi esitamine selleks, et maksimaalselt täpselt anda edasi mitte ainult intervjuu sisu, vaid ka psühholoogilist õhkkonda (Sommer \& Quinlan 2002: 76; Ives 1995: 79-80). Siiski on selge, et seda teoreetilist seisukohta pole võimalik sajaprotsendiliselt ellu viia (MacKay 2007: 50). Tavaliselt on mitteverbaalse kommunikatsiooni sisu rikkam ja sügavam kui transkriptsioonis (edasi)antud kommentaar. Kommentaaris näiteks saab näidata, et jutustaja naeratab. Parimal juhul on võimalik täpsustada, et naeratus on lõbus, irooniline, sarkastiline, juhuslik või muu. Kuid sellega ei saa väljendada peeneid psühholoogilisi ja antropoloogilisi nüansse, mida (loodetavasti) palju täiuslikumalt tajub teine kommunikatsioonis osaleja - intervjueerija.

Teiseks on tegelikult väga raske edasi anda intervjueeritavate kõne individuaalseid iseärasusi. Seda tunnistavad suulise ajaloo asjatundjad, kes enamasti ka nõustuvad sellega, et jutustaja kõne spetsiifilised tunnused tuleb jätta lindistusse, kuid loo kajastamisel peab järgima kirjakeele foneetilise norme (Baum 1991: 47; Ives 1995: 81; Sommer \& Quinlan 2002: 76). Siiski tuleb leksikas, morfoloogias ja süntaksis eelistada vestjale iseloomulikku, mitte normatiivset sõnade valikut, sõnade konstruktsioone, lausete struktuuri jms (Charlton et alii 2006: 252; Ives 1995: 81). Ebavajalike sõnade (mida kasutatakse pauside täitmiseks fraaside jms vahel) ja parasiitsõnade kohta tuleb märkida, et ena- 
masti ei ole nende kasutamine loo sisu mõistmiseks oluline, otse vastupidi nad segavad teksti tajumist ja sellepärast tuleks nad avaldatavast tekstist välja jätta. Erandiks on juhtumid, mil sellistel sõnal on mingi tähendus konkreetses olukorras (Baum 1991: 29).

Meie puhul tuli valestiütlemistele, kordustele, kokutamisele ja teistele tüüpilistele kõnedefektidele lisaks arvestada ka Latgale elanike kõne dialektoloogiliste iseärasustega nii läti kui ka vene keeles. Dialekti on raske kirjakeeles peegeldada ja suulise ajaloo praktikas ei loeta seda oluliseks puuduseks, sest on olemas ranged soovitused hoiduda dialektiliste iseärasuste lülitamisest transkriptsiooni (Sommer \& Quinlan 2002: 76). (Seejuures ei ignoreerita fakti, et küsimus dialekti kajastamise kohta võib olla väga tundlik, kui see puudutab dialekti kõnelejate poliitilisi seisukohti (Charlton et alii 2006: 252).) Latgale piirkonna polüetniline ja mitmekesine keskkond soodustab arvukate lingvistiliste laenude kasutamist, mille tulemusel vastaja öeldu pole kirjakeeles täpselt kajastatav. Jutustuse autentse kõla tabamiseks tuleb kuulata lindistust.

Kolmandaks, üks juba nimetatud multikultuurse keskkonna tunnuseid on laialt levinud kahe või enama keele sünkroonne kasutus ühe kõneakti raames. Suur osa inimesi on sellises keskkonnas kakskeelsed (isegi mitmekeelsed) ja nad kasutavad korraga kaht või enamat keelt: nad mitte ainult ei vali vastavalt olukorrale suhtluseks mõnda neile teadaolevatest keeltest, vaid ka lülitavad iseseisvalt kujundatud loosse sõnu, lauseid, isegi terveid fraase teistest keeltest. Sellisel juhul tekib küsimus, kuidas kirjalikult kajastada öeldut võimalikult originaalilähedaselt. See, kuidas kattuvad foneetiline (kõlav) ja kirjalik keel, sõltub mitmest asjaolust. Intervjuu mitmekordsel läbikuulamisel ilmneb, kui hästi oskab intervjueeritav keeli, kui sageli ta neid kasutab, kas ta oskab keelt või kasutab ainult mõningaid väljendeid jne. Transkriptsioonis võib see ilmneda vastavalt teises keeles vabalt ja õigesti öeldud fraasi visuaalse (kirjaliku) ekvivalendina või jutustajale iseloomuliku aktsendi visuaalse imitatsioonina. Näiteks ei kõla läti keeles antud intervjuus saksa keeles öeldud fraas päris saksapäraselt, sellepärast oleks õigem kajastus:

[---] vaatame koos emaga, sakslased toovad isa metsast ... [sakslased võtsid teda kaasa jooma], ja isa nii ei joonudki, noh seal mõne klaasikese, aga vist liiga palju oli temal ... Aga nad on käe alt võtnud, ... toovad [naerab]. Toovad ja ütlevad, kuidas nad ütlesid: "Isa haige, peab magama. Šlafen, fater, šlafen, fater krank" (DU MV: 216),

mitte “[---] Schlafen, Vater, schlafen, Vater krank."

Sarnaselt on ka vene keeles öeldud fraasidega lätlase eluloos: 
[---] siinsamas tulid meie omad ... žunda oli, ja siin ka ... Drozdiha selline: "Vi arestovani ..." noh ja sõdur. Nad ütlesid: "Nikuda ne uhodit, budte doma! Budte doma ..."Đ̈̈tles ja jäi sõdur. Sõdur see vene oli.

Venemaalt?

Venemaalt. Ta ütleb: “Sobiraites' $i$ berite vs'o s soboi, što možete."10 Inimene heast tahtest. Ma veel andsin talle sü̈̈a... (DU MV 195).

Kuid hoopis teine kõla on venekeelsetel ütlustel eluloos, mille venelasest jutustaja soovis jutustada läti keeles. Tema emakeel on vene keel, ta räägib vene keelt täiesti vabalt ja vähima aktsendita, seepärast peavad ka vene keeles öeldud fraasid kirjalikult olema kirillitsas vene keele grammatika ja interpunktsiooni norme järgides:

[---] Siis veeti veoautodega Nīcgale jaama. Kõik olid hirmunud. Ema ütleb isale: "Äkki jätame lapse naabritele? Sest ei ole teada, kuhu meid viiakse. Äkki lastakse kõiki maha...” Isa ütleb: “Умирать, так всем разом умирать..." Kuid siiski ta otsustas Vārkavas, sealsamas meiereis, seal selline tuttav inimene, Vaǵelis, töötas, ja ta andis mind sellele Vaǵelisele (DU MV: 72).

\section{Lõppsõna asemel}

Nii arhiividokumentide kui ka suuliste allikate avaldamiseks ettevalmistamisel tekib rida raskusi, eriti siis, kui püütakse mõlemat allikat avaldada kompleksselt. Kuid tulemusel saadavad uurimisvõimalused kaaluvad need raskused üle. Näiteks küüditatud Skladovide perekonna toimikus (LVA, fond 1894, nimistu 1 (Ilūkste maakond), säilik 8112) leidub kaks täiesti salajast teatist pere küüditamise kohta Ilūkste maakonna Salienase vallast. Esimese teatises on see kulakute perekond, mille peaks oli aastal 1890 sündinud Agafja Kirilli tütar Skladova. 25. märtsil 1949 oli see perekond (1 inimene) paigutatud Grīva jaamas ešeloni nr 97342 ja saadetud Omski oblastisse Lubina jaama, mida tõendavad Riikliku Julgeolekuministeeriumi töötajate Jermolajevi ja Aleksejevi allkirjad. Teises teatises on juttu natsionalist Jelisei Mihhaili poeg Skladovi (snd 1884) perekonna (samuti 1 inimene) küüditamise kohta 29. märtsil 1949 Eglaine jaamast Omski oblastisse. Ešeloni number - 97343, ametiisikute allkirjad - Trojanovs, Švedovs. Jutt käib loomulikult samast perest (selle tõendiks on arhiivis asuv üks ja ühine toimik), kuid kuidas seletada kokkulangematusi? Toimiku materjalides seletused puuduvad, ainult Jelisei Skladov on oma avalduses 6. juunist 1949 viidanud sellele, et ümberasumise ajal läksid 
nad naisega lahku (при переселении мы разъехались ${ }^{11}$ ), ja palus luba uuesti ühineda - tuua naine enda juurde või vähemalt saada luba tema külastamiseks. Jelisei ja Agafja Skladov olid küüditatud eraldi, alguses naine, hiljem mees. Sellele viitab erinev küüditamise koht, aeg ja ešeloni number. Seejärel Siberis nad said kokku, jätkasid ühist elu ja koos pöördusid tagasi kodumaale peale vabastamist. Kuid miks siis küüditati neid eraldi? Kus ja kuidas J. Skladov veetis küüditamiseelsed neli päeva? Kuidas sattus ta ešeloni? Kuidas nad kokku said? Pöördumata kaasaegsete tunnistuste juurde sõltuvad vastused neile küsimustele uurija kujutlusvõimest ja intuitsioonist. Võimalik, et perekonnapea peitis end (kuid miks üksi, ilma naiseta?), siis püüti ta kinni ja küüditati. Võimalik, et ta tuli ise (kuid mis sundis teda nii käituma?).

Küüditatud Skladovide lapselaps Jefrosinija, kes 8-aastasena oli vanavanemate küüditamise tunnistajaks, andis järgneva vastuse:

- Дедушка уехал на лошади в город, а бабушка [---] дома была одна. Значит, охраняли её. У неё связаны узлы лежали в доме. [---] Охраняли, значит, и ждали дедушку до вечера. Дедушка не приехал, и бабушку одну отправили. Вот... и дедушка приехал, может быть, через день бабушки нет. Мама... где-то были... дрова заготавливали с папой в лесу, а... а дедушка зашёл... зашёл, попросил: “Дайте мне иголку и нитки - чёрные и белые...” [заплакала] Вот. [---] я ему дала [иголку и нитки] (я была старшая в семье), и он ушёл... ушёл, поехал в Тартак. Там был [сборный] пункт и, значит, он отправился за бабушкой. Вот. И они тогда в Сибирь приехали, в Омскую область. То они там три месяца или что-то больше (я так из рассказов только знаю) не могли встретиться там с бабушкой. Не могли найти друг друга.

- Значит, в Тартаке он её не встретил?

- Нет, она уже была отправлена.

- Он просто пошёл и сам...

- А... а он пошёл... другим уже путём поехал. Один. Вот там они встретились. [---] Да. Вот потом они в 55-том году вернулись дедушка с бабушкой. [---]

- Как вам кажется, а почему всё-таки он устремился за бабушкой? [---]

- Нет, не говорили мы на эту тему. Ну, он... как преданность человека человеку. Отжили столько лет, дети взрослые, внуков куча.

[Vanaisa sõitis hobusega linna, vanaema [---] oli üksi kodus. Tähendab, valvati teda. Pambud olid tal kokku seotud kodus. [---] Valvati, tähendab, ja oodati vanaisa kuni õhtuni. Vanaisa ei tulnud, ja vanaema saadeti üksi minema. Vaat nii... ja kui vanaisa tuli, võib-olla nii päeva pärast 
- vanaema pole. Ema... kusagil olime... puid tgeime isaga metsas, aga... aga vanaisa tuli läbi... tuli läbi, palus: "Andke mulle nõel ja niit - must ja valge..." [hakkas nutma] Vaat nii. [---] ma andsin talle [nõela ja niidid] (ma olin vanim peres), ja ta läks ära... läks ära, sõitis Tartakki. Seal oli kogumispunkt ja, tähendab, ta läks vanaemale järele. Vaat nii. Ja siis nad sõitsid Siberisse, Omski oblastisse. Nii nad seal kolm kuud või kauem (tean ainult juttude järgi) ei kohtunud vanaemaga. Ei leidnud teineteist. Tähendab, Tartakis ta vanaemaga ei kohtunud?

$\mathrm{Ei}$, vanaema oli juba edasi saadetud.

Ja vanaisa läks lihtsalt ise...

Ta läks ... juba teist teed sõitis. Üksi. Ja seal nad kohtusid. [---] Jaa. Ja pärast juba 55-ndal aastal tulid nad tagasi - vanaisa vanaemaga. [---]

Mis te arvate, miks vanaisa ikkagi vanaemale järgi läks? [---]

Ei, ei rääkinud me sel teemal. See on... nagu ustavus inimesele. Elasid koos palju aastaid, lapsed on täiskasvanud, hulk lapselapsi] (DU MV: 180).

Seega saab julgelt väita, et Jelisei Skladov läks ise kogumispunkti ja andis end repressiivorganite käsutusse, et järgneda naisele. Ametlikult ei tunnistata seda sammu vabatahtlikuks, sest vana mees on küüditatavate nimekirjas, kuid inimlikult oli see tema enda tehtud valik.

Paraku ei ole meil enam võimalik teada saada Jelisei Skladovi vastust küsimusele, miks tegi ta just sellise valiku, samuti ei ole meil võimalust teada saada vastuseid paljudele teistele küsimustele seoses küüditatute tunnete, motivatsiooni, väärtustega, sest suurim osa neid inimesi on juba igavikku lahkunud. Sellepärast peame me kiiresti rääkima nendega, kes on meie seas, ja nende antud informatsiooni tuleb kindlasti kasutada ajaloo-uurimustes koos teist liiki allikatest saadud informatsiooniga.

Läti keelest tõlkinud Valts Ernštreits, vene keelest Viivika Orula.

\section{Kommentaarid}

1 Lätis samuti nagu Eestis vahetus ajavahemikus 1940-1944/45 järjest kommunistlik, natsistlik ja jälle kommunistlik režiim, mis lakkas olemast 1991. aastal.

${ }^{2}$ Vt ka DU MV 8, 21, 24, 28-30, 34, 36, 43, 48, 57, 108, 130, 136, 145, 150, 153, 157, 159, 160, 180, 194, 195, 214, 216, 222.

${ }^{3}$ Kui surra, siis kõik koos (vene k, toim).

${ }^{4}$ Need toimikud on alustatud 25. märtsil 1949, kuigi mõned dokumendid on ka varasemad; toimikute koostajad olid Läti NSV Riikliku Julgeolekuministeeriumi kohalikud asutused. 
5 Isiklikud toimikud on alustatud aprillis 1949, nende koostamisega tegelesid NSVL Siseministeeriumi erikomandatuuride töötajad küüditamise sihtkohtades.

${ }^{6}$ Operatiivvolinik (vene k, toim).

7 Eriasumine (vene k, toim).

8 Olete arreteeritud (adapteeritud kirjapilt, vene $\mathrm{k}$, toim).

9 Ärge minge kuhugi, olge kodus! Olge kodus... (adapteeritud kirjapilt, vene k, toim).

${ }^{10}$ Korjake kokku ja võtke kaasa kõik, mis saate (vene k, toim).

11 Ümberasustamisel sattusime lahku (vene k, toim).

\section{Allikad}

DU MV - Daugavpilsi Ülikooli suulise ajaloo keskuse kogu

LVA - Läti Riigiarhiiv

NMA -Läti elanike elulood rahvusliku suulise ajaloo projekti kogu

\section{Kirjandus}

Baum, Willa K. 1991 (esitrükk 1981). Transcribing and Editing Oral History. Walnut Creek, Lanham, New York, Oxford: AltaMira Press.

Charlton, Thomas L. \& Myers, Lois E. \& Sharpless, Rebecca (toim) 2006. Handbook of Oral History. Lanham, New York, Toronto, Oxford: AltaMira Press.

Friedlander, Peter 1998. Theory, method and oral history. Perks, Robert \& Thomson, Alistair (toim). The Oral History Reader. London: Routledge, lk 311-319.

Grele, Ronald J. 1998. Movement without aim: Methodological and theoretical problems in oral history. Perks, Robert \& Thomson, Alistair (toim). The Oral History Reader. London: Routledge, lk 38-52.

Ivanovs, Aleksandrs 2002. Mutvārdu vēstures avoti - iemiesotā atmiņa. Ķikāns, Valdis (toim). Atmiņa kultūrvēsturiskā kontekstā: Starptautiskās konferences materiāli. 2. dậa. Daugavpils: Saule, lk 75-84.

Ives, Edward D. 1995 [esitrükk 1980]. The Tape-Recorded Interview: A Manual for Fieldworkers in Folklore and Oral History. Knoxville: Universiy of Tennessee Press.

MacKay, Nancy 2007. Curating Oral Histories: From Interview to Archive. Walnut Creek, California: Left Coast Press inc.

Pravila 1990 = Правила издания исторических документов в СССР. Москва: Главное архивное правление при Совете Министров ССР.

Saleniece, Irēna 2002. Vēsture un atmiṇa: vēstures fakts laikabiedru atmiṇās. Ķikāns, Valdis (toim).Atmiṇa kultūrvēsturiskā kontekstā: Starptautiskās konferences materiāli, 2. daļa. Daugavpils: Saule, lk 67-74.

Saleniece, Irēna 2005. Pagātnes bailes mūsdienu skatījumā. Sociālo zinātṇu vēstnesis 1, lk 63-72. 
Saleniece, Irēna (toim) 2008. 1949. gada 25. martā izvesto balsis: Dažu Daugavpils un Ilūkstes apriņ ķa deportēto gímeņu likteņi mutvārdu vēstures avotos un arhīva dokumentos. Daugavpils: Saule.

Sommer, Barbara W. \& Quinlan, Mary Kay 2002. The Oral History Manual. Walnut Creek, Lanham, New York, Oxford: AltaMira Press.

Thompson, Paul Richard 2000. The Voice of the Past: Oral History. Oxford: Oxford University Press.

Zirnīte, Māra 1996. Nacionālā mutvārdu vēsture: Modelis un interpretācija. Latvijas Zinātņu Akadēmijas Vēstis A, 4/5, lk 138-142.

Zirnīte, Māra \& Hinkle, Maija (toim) 2004. Mutvārdu vēstures avoti: Izlase. Rīga: Latvijas Universitātes Filozofijas un socioloğijas institūts. Nacionālās mutvārdu vēstures projekts.

Sokolov et alii 2004 = Соколов, Андрей \& Бокарев, Юрий \& Борисова, Лариса. Источниковедение новейшей истории России: теория, методология, практика. Учебник. Москва: Высшая школа.

\section{Summary}

\section{History of Latvia in the Twentieth-Century as Reflected in Historical Sources: Dialogue between Oral History and Archival Records}

\section{Irēna Saleniece}

Key words: archival documents, complex source publication, interviews, deportations of March 1949, 20th-century history of Latvia

The article explicates the need to use oral history sources together with other types of sources in the study of the history of Latvia in the 20th century, to discover facts that have been kept concealed so far, and to render the view of the past in a more accurate and versatile manner. Oral history sources are the only ones that enable us to attempt to reconstruct from the contemporary perspective how people who took part in historical events provided motivation, justification, and explanation for their behaviour in different situations. The author observes a situation described in archival records and in the life stories of two women, a mother and a daughter, living in eastern Latvia. The central event of both stories is the deportation that took place on $25 \mathrm{March}$, 1949. This article is based on an analysis of problems encountered when compiling the collection The Voices of the Deported, 25 March 1949: The fate of some deported families from Daugavpils and Ilūkste districts in oral history sources and archival documents. The information from oral history sources supplements, clarifies, and sometimes contests the archival documents; the use of oral history sources gives a clearer view of the contrast between the official and the individual perception of the same facts. Relying on the author's experience in preparing a source publication, the article deals with the legal and ethical problems related with the complex publication of archival documents and oral sources, and the issues connected with the archaeography of sources. 